\title{
Chapter 5 \\ Return to Sender: Remittances, \\ Communication and Family Conflict
}

\begin{abstract}
When I have my family on the telephone, they ask for money. What money? Am I supposed to steal it? [Interviewer: Your children, do they understand the difficulties you have, or are they not aware of the situation?] They know, they know. But they are demanding (...) I have to send them cash, buy them things, look after my own health. I don't know which way to turn.
\end{abstract}

Excerpt from the film, Un jour, je repartirai..., a documentary film about older hostel residents directed by Chantal Richard 2002 [author's translation]

Chapters 3 and 4 focused on the French context of the hostel residents' lives. The current chapter and the one which follows it will connect to the context of origin. In this present chapter I will discuss the relationships which these 'geographically single' men have with their 'left behind' families, before proceeding in Chap. 6 to the question of hometown development initiatives which some hostel residents engage in.

Turning to family first, I have already noted the extent to which the biographical particularity of being geographically single is implicated in hostel residents' difficult passage to retirement and the dilemma they face regarding return, notably as regards their reduced access to sources of informal care within their families. The present chapter shows how certain unexpected developments in transnational family relationships also influence the mobility of the older hostel residents and their return decision-making after retirement. These developments are grouped under three themes:

- Continued dependency on remittances after the retirement of the male breadwinner in France;

- Departures from normative family roles which give rise to gendered and generational conflicts;

- Advances in communication technologies which amplify this dependency and conflict.

In what follows, I will show that while a culture of male emigration emerged in places of origin which initially reinforced gendered family structures, for some hostel residents the spectre of continued family separation beyond retirement ends 
up disrupting such patriarchal norms, leading to greater autonomy for left behind wives. Thus, the term 'left behind' describes a heterogenous range of situations and is not necessarily always connoted with negative outcomes for non-migrant kin, as other authors have also found (Jónsson 2011; Lenoël 2017; Mondain and Diagne 2013). However, before analysing these developments further, it will be helpful to clarify the importance of remittances for hostel residents and their left behind relatives, and to provide information on how they are sent and spent.

\subsection{Breadwinner Migrants: Remittance Sending as a Way of Life}

As noted in Chap. 2, the hostel residents emigrated to France to financially support their parents and/or young families as male providers, or what Kitiarsa (2009) labels 'breadwinner' migrants. Remittance sending has thus constituted a way of life since the hostel residents first arrived in France (Barou 2001; Gallou 2005). From the early 1970s, surveys of remittance sending showed that migrant workers in France were poorly paid but saved hard, with hostel residents of all nationalities remitting around a quarter of their income (Les Echos 1971; Ginesy-Galano 1984). A culture of breadwinner migration developed readily in North and West African sending regions where society is structured according to patriarchal norms, and in which men achieve social status by accumulating wealth and taking sole responsibility for household material needs (Bourdieu 1965; Manchuelle 1997; Mondain and Diagne 2013).

It is important to acknowledge that those left behind are not necessarily equal in their access to remittances and that one may distinguish a certain hierarchy of entitlement, which is in part religiously mandated in Muslim North and West Africa. In Islamic family law, husbands are enjoined to provide financially for their wives (nafaqa) but, especially in the early years of emigration, wives rarely receive or make decisions concerning remittances. Instead remittances are directed first and foremost to fathers or mothers, or if they are deceased, to brothers or sisters (Bourqia et al. 2007). Such filial devotion is particularly commended in Islam. However over time, as Audrey Lenoël (2017) has found, left behind wives may gain in authority and responsibility, particularly if they no longer have to care for their husbands' (now-deceased) parents, enabling them to establish a separate nuclear household with their children. Nonetheless, such family dynamics are complex and left behind parents or siblings may strongly resist a wife's autonomous tendencies (Lenoël 2017).

In interviews, my respondents highlighted the 'pressures' they faced to provide for the needs of these different constituencies. Waly (75, from Kayès in Mali) was quick to highlight the differences between his simple solo lifestyle in France and the broad responsibilities he shouldered as household head vis-à-vis his family in Mali. 
The role of breadwinner was so fundamental to my respondents' self-understanding that they continued to identify with it despite having retired, as Waly notes:

We live in this solitude, but over there [Mali], there's more responsibility. Here [in France] we just have to take care of ourselves, our health etc, but over there, you're the dad, you're the head of the family who must look after everyone, who must take care of all sorts of problems. (Waly, 75, Kayès, Mali)

While initially a means to support left behind relatives in material and economic terms, remittances have also served a social and psychological function for those earning and sending this money. This echoes an insight from Jørgen Carling (2014) who urges researchers to view remittances holistically as compound transactions, bound up both with material concerns and the emotional content of social relations. Studies of hostel residents have depicted remittance sending as a form of atonement for absence (Aggoun 2006; Hmed 2006), and this is amply demonstrated by the asceticism of the hostel residents' lives. An ascetic existence was worn as a badge of honour by some whom I spoke to, and other scholars have noted the social status and respect associated with remittance sending, fostering psyschological well-being (Riak Akuei 2005). Lindley (2009: 1327) writes that 'remitting can be a source of familial and cultural reaffirmation... being able to support relatives can make a painful separation seem more worthwhile.' One respondent, Hamid (70, Taroudant, Morocco), described how he is responsible financially for his whole family, even the oldest children. Indeed he reported - with some pride - giving money to his sisters and brothers, for weddings, feast days and festivities. "It does good. It's important to give to one's relatives." Anne-Marie, a crisis social worker, noted:

the only thing which they still have is the pride of being able to send something to their families over there and to be autonomous here in France (...) They are always very happy when we go to see them in their rooms, they are always happy to say how many children they have, how much they send each month.

Importantly, the system of hostel accommodation has facilitated and institutionalised these remittance sending practices. As was argued in Chap. 2, one of the state's primary aims in building low-rent hostels was to limit family reunification by facilitating high levels of remittances. This would benefit workers' families more than would have been the case had the latter come to live in France, where the cost of living was far more expensive (Viet 1999). Of course, it was never envisaged that the hostels would continue to provide housing for the same migrants half a century later, and indeed a large proportion long ago left the hostels - either to return home or to reunify in France with their families (see Chap. 1). Nonetheless the current long-term residents, now retired or approaching retirement, have internalised this founding logic of the hostels, by continuing to send remittances. The ones who remain, "the people who haven't abandoned the concept of the hostel" as one senior civil servant put it to me, "are those who have had no personal project other than to remain in a situation of sending money back home." In other words, the older hostel residents are institutionalised in this remittance-sending logic, bearing out Hmed's (2006) contention that the hostels represent a form of 'total institution' (see Sect. 2.4). 
Contemporary Remittance Sending Practices A comparison with the abovementioned remittance surveys from the 1970s shows a similar proportion of income remitted by current hostel residents (Bitatsi Trachet and El Moubaraki 2006). My own observations support this. In most of my interviews I asked respondents if they would mind telling me how much they remitted each month. To be sure, not everyone felt comfortable disclosing this type of information given its sensitive nature. ${ }^{1}$ However, for those willing to divulge such details, the sums ranged from 25 to $40 \%$ of monthly income, depending on the particular outgoings incurred each month. Such proportions are in line with the findings of a study conducted by the Moroccan Government in 2005, which showed that less educated Moroccans aged 40-65 are likely to remit larger sums (Berrada 2009). As the monthly income for most of my respondents was in the range of €600-€1000, typical sums remitted are €150-€250 per month, but this could rise to $€ 400$ in auspicious or urgent circumstances.

While the proportion of income remitted today is comparable with the sums sent in the 1970s, the means of sending money have evolved over time. Initially, the standard method in the past was via postal order (mandat). In certain cases the ubiquity of this method prompted the construction of post offices in migrants' home villages. However, costly transfer fees and lengthy delays in delivery led to the progressive abandonment of postal methods during the 1980s in favour of much faster transfer services such as Moneygram and Western Union (Tall 2004). While quicker, these services also charge substantial fees and commissions (Hamel 2009). As a result, even in this age of electronic transfers, one should not ignore the continued significance of informal practices, such as carrying cash in hand luggage when travelling home, or entrusting money to relatives or friends who are travelling, with instructions as to who should receive it. I observed such informal practices on several occasions, and indeed was asked to carry money for one of my respondents during my trip to Senegal. This vital cash-handling function is of course a further impetus for the back-and-forth visits which the older hostel residents undertake.

How Remittances Are Spent As mentioned, many residents felt uncomfortable disclosing their family finances. Among those who were less reluctant, however, the case of Ibrahima (59, Gorgol, Mauritania) was typical. A kitchen porter at a restaurant near Gare Saint-Lazare in Paris, he readily supplied a very detailed breakdown of his monthly expenses, both in France and Mauritania. He works 35 hours per week, and earns the minimum wage, giving an income of just under $€ 1050$ a month (net) in 2009 when I interviewed him. His monthly expenses in France are detailed in Table 5.1.

Taking his monthly outgoings of $€ 564$ away from his net income of $€ 1050$, what remains is a sum of $€ 486$. This tallies with what he remits every month: a minimum of $€ 250$, occasionally rising to $€ 400$. Ibrahima insisted that " $€ 250$ is good in Mauritania." He has sixteen family members in his charge, including his motherand father-in-law. Every month, his family's grocery bill in Mauritania amounts to

\footnotetext{
${ }^{1}$ During my fieldwork in Dembancané (Senegal), I was formally requested by the town's deputymayor not to ask my respondents this question.
} 
Table 5.1 Ibrahima's average monthly outgoings in France

\begin{tabular}{l|c}
\hline ITEM OF EXPENDITURE & COST $(€)$ \\
\hline $\begin{array}{l}\text { Rent (net of APL housing } \\
\text { benefit) }\end{array}$ & 216 \\
\hline Groceries & 150 \\
\hline Public transport: travel pass & 90 \\
\hline Private health insurance & 50 \\
\hline Telephone: landline rental & 20 \\
\hline Hometown association: dues & 30 \\
\hline Trades union: dues & 8 \\
\hline Total expenses & $€ 564$ \\
\hline
\end{tabular}

over $€ 100$, purchased from the local co-operative in his village. On top of this, there are regular expenses which he must cover, such as medical bills, (grand)children's schooling, property upkeep, and agricultural equipment.

Providing for the subsistence needs of the extended family is the bare minimum which is expected. The aspiration is that migrant earnings will also permit the accumulation of sufficient capital to bring about a change in the social status of the family in the country of origin. The purchase, construction or improvement of the family home is one such opportunity for visibly improved status, and was identified as one of the benefits of emigration by almost all respondents (see also Sect. 6.2). Only one of my respondents mentioned that his family lived in rented accommodation: the others were all home owners. Home ownership and/or improvement is not just a means of demonstrating social mobility to one's neighbours: for some respondents, it was a motivational aid to inspire their children to work hard in the future, a visible manifestation of "what papa has been able to do, what his work has achieved, he worked hard" (Ibrahima, 59, Gorgol, Mauritania).

There is nothing particularly novel about these resource allocation decisions: the aspiration to buy or build a home in the community of origin has been recorded in many studies across different historical periods (for examples, see King 1986; ObengOdoom 2010; Parreñas 2005; Wyman 1993). What is perhaps "innovative" (Cerase 1974: 261) is that migrants are investing in property not only for their families' needs, but also for rental purposes, thereby diversifying once again the family's income streams. This explains in part the rapid growth of regional urban centres in prominent migrant sending areas of North and West Africa, as documented by other authors (Berrianne and Hopfinger 1992; Lacroix 2005; Quiminal 2002). Rental investment was also mentioned in my own data. Abdoulaye (44, Tambacounda, Senegal) has built a large house for his family in Bakel, Senegal, but he has also started building a second house of three storeys in Dakar, which he plans to rent out. This rent will bolster his French pension when he comes to retire. According to Abdoulaye, many Senegalese emigrants have adopted this real-estate strategy for their retirement. Ibrahima (59, Gorgol, Mauritania) likewise has built two houses in his home village, as well as a house in Dakar, which he currently rents to tenants. He also has ambitions to build a second rental property in Nouakchott, the Mauritanian capital.

While house-building was identified as important by almost all respondents North African and West African alike - other uses of remittances seem to be favoured 
by one group but not by the other. For example, many West Africans with whom I spoke gave considerable priority to agriculture. Idrissa (Dembancané, Senegal) explained that since farming helps to feed the family, much remittance money is spent in this domain. Ibrahima (59, Gorgol, Mauritania), for example, had imminent plans to travel to Belgium to complete the purchase of a tractor, which he will then ship to Mauritania. Issa's goals were more modest:

Before, I used to work but I didn't save much, because back home there is the big household, but only me to provide for them, for food, for medicine if someone is ill. When I was able to save, I invested in livestock. (Issa, 70, Tambacounda, Senegal)

By contrast, very few North African respondents reported devoting remittances to agriculture, consistent with other literature on migration and development in Morocco (see de Haas 2006 for discussion). What was far more important to Moroccan and Algerian respondents was the education of children, especially a university education. Interestingly, the respondents who stressed education in their accounts were committed to a higher education both for their daughters and their sons, whereas other studies of remittance use in North Africa have found that due to cultural reasons sons are more likely to benefit from remittances for post-primary education (Bensaid and Ibourk 2008). Given the purposive rather than representative nature of the respondent sample, my findings here may not be indicative of wider trends. Be that as it may, what emerged repeatedly in several of my interviews was the idea that hostel residents had been 'working for the next generation', a finding also underlined in a report about the impact of remittances in Morocco (Bensaïd and Ibourk 2008):

We didn't get to go to school. We mustn't leave our children like that, without education. (Hamid, 70, Taroudant, Morocco)

I have children. They study - because I didn't have the chance to pursue my studies. It was a question of poverty or bad luck, because my parents died when I was young. (Saleem, 60, Tiznit, Morocco)

For Saleem and Hamid, giving their children the gift of a good education is important precisely because it was something which had been denied them in their youth. It is also important insofar as it may determine the capacity of children to take on the responsibility of providing for the household once the father retires in France, with consequences for return decision-making as will be shown below. Conversely, for my West African respondents, education was not highlighted as a goal for individual families, but rather as a communal endeavour, hence the substantial collective remittances devoted to school-building projects in the villages of several of my respondents. The same applies to health clinics and other types of infrastructure benefiting local communities (see Chap. 6 for details). While collective approaches to such provision also exist in Morocco - the efforts of the NGO Migrations et Développement are one example (Lacroix 2005) - amongst my respondents the tendency was for the onus to lie with individual migrants (see Sect. 6.3). 
In summary, remittances sustain the lives of those remaining back home, and satisfy their basic subsistence needs. Be it on an individual family basis, as in North Africa, or on a wider community basis, as in West Africa, these remittances constitute a social safety net (protection sociale) ensuring stability and minimising risk to family income. This analogy with the welfare state was made time and again by respondents. However, in addition to the subsistence aspect, remittances also function to bolster esteem and status. This can be seen in the houses which migrant families build and improve, as well as investments in agriculture and education for children. What is perhaps less clear is the relevance of the above to the central issue interrogated in this book, namely return migration decision-making at retirement. It was argued in this first section that the hostel has in fact institutionalised remittance sending practices. It was also hinted that education and the readiness of children to take on household responsibilities may have a bearing on whether hostel residents are able to return. Following retirement, a certain dependency on the remittances sent by these ageing breadwinners may persist, as will be discussed in the next section.

\subsection{Continued Dependency on Remittances Past Retirement}

Chapter 1 outlined economic theories of migration which predict return at retirement for North and West African hostel residents whose families have remained behind in the country of origin. Neo-classical economists argue that at retirement wage differentials between home and host countries no longer influence migration decision-making: instead what is important is the purchasing power of the migrant's pension, which in most cases is fully transferable thanks to the bilateral social security agreements which operate between many labour-exporting and importing countries (de Coulon and Wolff 2006; Klinthäll 2006). The calculation in most instances is a 'no-brainer', since costs of living tend to be far lower in migrants' home countries, offsetting any potential losses in currency exchange fees which may accrue if the pension is transferred home. Return home is the rational choice.

For some respondents the neo-classical logic remains valid. Dr. Ismail, an Algerian geriatrics specialist who runs a free health advice service in several Parisian hostels, argued that a monthly pension of $€ 200$ or $€ 300$ was sufficient for an older couple living in Algeria. Issa (70, Tambacounda, Senegal) felt that with $€ 500$ each month one could live very comfortably in Senegal. Djimé (Dembancané, Senegal) agreed:

When you are a pensioner [here in Senegal], you live comfortably, you're not the same as those who don't have any resources, who don't have a pension. It's not the same life. Really, when you are a pensioner, you can live better here.

However, the lack of definitive return at retirement by hostel residents calls into question these neo-classical tenets. Perceptions of individual wealth must be tempered by the size of the family in the pensioner's charge. For these respondents, it 
does not make sense to talk of individual economic decision-making. Rather, it is the new economics of labour migration (NELM) approach which has primacy. In this theoretical paradigm pioneered by Oded Stark and colleagues, retirement implies the end of the migration project and subsequent return home to rejoin children, who take on the responsibility for the household (Stark 1991). For some hostel residents, retirement means that there is less of an obligation to send remittances:

Now it's up to them to get by. (Fouad, 60s, Constantine, Algeria)

The other children can manage for themselves. It's normal. (Mehdi, 64, Chlef, Algeria)

I'm going to rest and enjoy my retirement: my kids will do the work. (Habib, 65, Oran, Algeria)

These three testimonies support the NELM assertion that an inter-generational transfer of responsibility in providing for the needs of the family occurs when the migrant breadwinner retires. Yet this transfer of responsibility does not necessarily lead to definitive return. In these three cases, the men have remained in France, but their non-return is not presented as an economic issue. Instead, it is justified on health grounds, as was elaborated in Chap. 4.

For other respondents, however, the NELM logic becomes distorted and the assumption of transferring household responsibility to adult children is called into question. In these cases, the duty to provide for a significant number of dependents after retirement weighs heavily. Respondents often enumerated the many family members remaining in their financial charge past retirement. 70-year-old Issa (Tambacounda, Senegal) for example still has seven children living at home, some of whom are still at school. Hadyatou (Dembancané, Senegal), although in his 70s, has several children still at school, some at primary level. Further financial difficulties arise when respondents' children start their own families, but without the income from regular employment to satisfy the new needs which result, due to the difficult job market for young adults in many parts of North and West Africa. As a consequence, new additions to the family were not always perceived as an unqualified source of joy for grandfathers in France. This was captured very well by Saleem (60, Tiznit, Morocco):

$90 \%$ of us are trapped in this situation (...) So we - excuse my language - but we become slaves, of ourselves. Because when you have a child and that child gets married, you have to work for the grandchildren too (...) we have to provide for the grandchild, and for me the grandchild ....well, it's a bit much.

The education of children was identified as key, in particular by North African respondents. Dr. Ismail, a geriatrics specialist working with hostel residents in Paris, was adamant that continued family dependency was inversely related to the education level of the children: "Those who have invested in their children's education reap the benefits". By 'benefits' uppermost in my respondents' eyes was finding well-paid employment. However, it is important to note that investing in children's education has not always paid off, as the high graduate unemployment rate in countries like Morocco attests (de Haas and Fokkema 2010). Some of my respondents mentioned these dashed hopes. However Mehdi (64, Chlef, Algeria) had a more positive story to tell. Of his eight children (aged 26-45), five passed the Baccalauréat 
school leaving certificate: his eldest son is an engineer, and two other children are high school teachers (Mehdi, 64, Chlef, Algeria). All of them speak French very well. He never forced them to study, but he always encouraged them. "If they passed the Baccalauréat, I would buy them a present." Yet he remarked that if they had come to France they would not have been able to get a job: in Mehdi's view there are no jobs for the children of immigrants, because of job market discrimination. This rationale for not undertaking family reunification also emerges in other research (e.g. de Haas and Fokkema 2010).

Not all emigrant fathers have been as diligent as Mehdi, according to Lahcen who works for a rural development NGO in Taroudant Province, Morocco: 'one of the major sins committed by the retired hostel residents [is that] they haven't pushed their kids to work. The son is 40 years old but does nothing ... he stays at home all day watching television, and asks for some pocket money to go buy a coffee.' Of course, this is not to say that that children's academic success is solely down to fatherly influence: regardless of the migrant breadwinner's preferences, education may not be prioritised by adult relatives left behind. Furthermore, those expecting to join their father in France at some point may see no point in applying themselves academically. The steady income of remittances may act as a disincentive, leading to freeloading behaviour (comportements de rente; see Bourqia et al. 2007). ${ }^{2}$ Moussa (55, Mali) viewed such attitudes as part of a broader materialism among left behind relatives, evidenced by the requests for goods such as mobile phones, televisions and home entertainment systems which hostel residents are expected to bring as presents when they return. Moussa labelled this an "inculcated mentality of dependence-assistance (...) The traditional type of society is in the course of being destroyed, transformed into a society of assistance and dependence... a parachuted comfort" (Moussa, Mali).

In sum, the passage to retirement does not always reduce the burden of financial dependency of left behind family members. Hostel residents in this situation have not reckoned on continued dependency past retirement. Most crucially, because of this persistent family dependency on their earnings, some of my respondents chose to remain in France to receive social security benefits, which helped to finance their families' outgoings. As was noted in Chap. 3, hostel residents over the age of 65 in receipt of modest pensions are eligible for the Allocation de solidarité aux personnes âgées (ASPA), colloquially known as the minimum vieillesse, a means-tested noncontributory benefit which tops up the state-administered pension to a minimum old-age income, set at $€ 708.95$ per month in 2010 when this research was completed. Receiving this benefit enables the family to attain solvency, but only at the cost of the hostel resident residing in France for at least 6 months per year in order to satisfy the residential conditions of eligibility. It is to be underlined that in no way is recourse to the minimum vieillesse a manifestation of individualistic neo-classical behaviour: the extra money is channelled to family dependents, not retained by the

\footnotetext{
${ }^{2}$ Against this view, de Haas (2006: 571) found that international migrant households in the Todgha Valley (south-eastern Morocco) were not "passively relying" on remittances and did not withdraw from local economic activities.
} 
migrants for personal consumption. It is also to be underlined that receiving the minimum vieillesse was more a feature of North African narratives. However, a few West Africans admitted claiming it:

Now I am old, I'm not able to work. At retirement what I earn isn't enough for me to live with my children, with my wife (...) So I requested the minimum vieillesse, it helps a bit. It's better now. (Issa, 70, Tambacounda, Senegal)

Other researchers have also documented these financial constraints on return migration, prolonging the geographical separation of families after the retirement of the principal wage earner in France. Because of the minimum residence conditions associated with welfare entitlements, "these migrants become hostages to France, although their state of health or age would point in favour of an extended return to their family back home" (Bitatsi Trachet and El Moubaraki 2006: 104). Choukri Hmed likewise describes this situation as a form of "house arrest" in France (2006: 122). Notwithstanding these points, for some hostel residents non-return at retirement was not just a function of financial viability for households in places of origin, but also a response to a perceived loss of control over their families, leading to conflict and resentment. This theme will be discussed in the next section.

\subsection{Gender, Generation and Conflict in Transnational Families}

The foregoing discussion has demonstrated a central feature of life for some older hostel residents, namely the retention beyond retirement of the dominant social role of breadwinner. In this regard, their experience of old age differs from the norm in European host countries. The social gerontology literature holds that older people in (post-) industrialised countries undergo a process of 'role loss' as they advance in years, and the passage to retirement is a critical juncture in this process (Gordon 1972). To the extent that this literature has distinguished the gendered aspects of ageing, elderly men in particular are singled out as experiencing loss of roles and resources (Thompson 2001). For the hostel residents, the transition to old age is more complex. On the one hand, hostel residents paradoxically have been able to retain some roles that normally they might be expected to shed upon retiring in France. A case in point, in addition to the breadwinner role, is that some elderly respondents were fathers to school age children. On the other hand, however, hostel residents also risk losing roles which typically would be ascribed to them at their stage of seniority in the place of origin, particularly roles based on patriarchal family norms. The normative obligation to fulfil the gendered role of breadwinner prolongs absence and may spark family conflicts, which in turn may call into question the patriarchal family values which structure social relations in communities of origin (Mernissi 2003; Sharabi 1988). As will be described below, wives, children and siblings who have stayed behind may gain in autonomy at the expense of older hostel residents (cf. de Haas and Fokkema 2010). This applied less to West African 
respondents however: while there are some West African testimonies on this theme, most of the voices below are North African.

There was sometimes resentment from hostel residents at the authority which wives have been able to gain over time, particularly following residential and household independence from parents-in-law, as Lenoël (2017) describes. "A woman is like a wallet" said one North African resident, "she keeps your money." Indeed, there is potential for the wives of hostel residents to overturn the patriarchal model of family roles, by assuming control over the household budget, children's education and discipline, and so on. As Idrissa (Dembancané, Senegal) sees it, after years of living apart the wives have their own habits and the men have theirs, and it can be very difficult to reconcile these two lifestyles following the husband's return. The result is "a clash of personalities", occasionally resulting in divorces at retirement. After a certain time away from the village -

One loses one's bearings as the head of the household. Likewise the wife has lost the habit of living together. (Souleymane, 50s, Mauritania).

As a result, some men only stay for a few months back home, because they get annoyed with their families. "We get fed up, and decide to come back" (Kemal, 63, Algeria). Although family problems may not always be openly admitted, such bitterness and grudges can lead to return trips being postponed or cut short, as the following quote suggests:

It is like I was telling you last time, people here stay in France because of their health. But actually it's probably a problem of stress with their families. They hold out, hold out, and then - bam - they crack, an illness (...) They don't talk about this sort of thing, these are things which are not talked about. They hide the real roots of the problem. (Saleem, 60, Tiznit, Morocco)

A similar loss of control may arise in inter-generational relationships with grown-up children. One of the principal difficulties of migrating alone and not reunifying one's family in France is that "you risk losing your children" (Hamid, 70, Taroudant, Morocco). Being away from home for long periods during working life means that as a father one does not see one's children growing up: "they end up not knowing their kids" (Idrissa, Dembancané, Senegal). This is particularly the case for West Africans of working age, who often spend 2 or 3 years in France at a stretch between return visits (see Sect. 1.2). During my fieldwork in West Africa I was privileged indeed to witness several family reunions. While full of joy, the expressions on the faces of the children sometimes betrayed a sentiment of uncertainty and anxiety, especially among younger children: it appeared that their fathers were to some extent 'strangers' to them. Over time, this enforced estrangement can lead to less than respectful relations between fathers and children, as work by Jacques Barou has comprehensively revealed (Barou 2001). De Haas and Fokkema (2010) documented the resentments which adult children harbour towards their migrant fathers, particularly regarding the decision not to reunify the family in Europe, where the children imagine a brighter future. Denis, a hostel manager, noted that, "They slave away here for their children, but their children aren't grateful." Even harder for some fathers to bear is the perception that their children behave in the 
same way as young people in France, in other words like 'delinquents' (voyous) as several respondents put it. Kader (70s, Mostaghanem, Algeria) noted this "moral degeneration" of youth in his home country, as did Ferouah: "The new generation of children fall easily into delinquency. They get bad habits. They steal, they take drugs, they don't respect their parents" (Ferouah, 60s, Morocco). Hadyatou (Dembancané, Senegal) had this to say:

It doesn't give me pleasure to say this but the youths of today are very difficult. In our day, when our parents told us to stay here-or-there, or do this-or-that, we listened. Whereas nowadays the young ones don't listen to their parents.

It might be tempting to interpret the preceding quotations as merely the disgruntled grumbles of husbands complaining about their 'nagging' wives and 'ungrateful' children. At times there was an element of this which crept into my discussions with older hostel residents, but their remarks cannot be passed off as mere moaning. There was a considerably heightened level of emotion when some men talked about their "enslavement", "exploitation", "pressures", "burdens" and "responsibilities" which went beyond everyday complaints about nagging relatives. The gravity of such words is sufficient to make that clear.

In summary, the result of these accumulated conflicts is that the hostel becomes a 'refuge' from family problems. They come to France for paperwork or healthcare, and upon their return to Morocco there will be a family row - "a banal conflict" and they will be off to France again. "When he returns [to France], it's true he returns for healthcare, but when he is back he is relieved (...) It's a refuge for him", as Saleem (60, Tiznit, Morocco) put it. As noted, one of the sources of tension in these transnational family relationships is the increased materialism of children and other 'left behind' relatives, eager to enjoy the "parachuted comfort" of consumer goods and modern communication technologies such as mobile phones. Ironically, such technologies may serve only to further amplify remittance dependency and family tensions, as will be described below.

\subsection{Communication Technologies: Impeding Not Empowering Return ${ }^{3}$}

In the overview of theories presented in Chap. 2, the literature on transnationalism emerged as a key body of work for understanding return migration and back-andforth trips. It was shown that this literature sets great store in technological advances which facilitate social, economic, political and cultural connections between migrants and their homelands. Developing this insight, I will now discuss the question of whether using information and communication technologies (ICT) can

\footnotetext{
${ }^{3}$ The following section is largely reproduced from my open-access article: Hunter (2015a) Empowering or Impeding Return Migration: ICT, mobile phones and older migrants' communications with home, in Global Networks 15: 4, pp. 485-502
} 
empower migrants to return. In the last two decades, transnational migrants' communications with their left behind families have been transformed by advances in technology, particularly mobile phones and cheaper landline calls. A growing literature on the use of ICT in transnational social fields, has noted the empowering and uniting effects of these technological advances, both for migrants and their left behind relatives and friends (Horst 2006; Madianou 2012; Panagakos and Horst 2006; Tall 2004; Thompson 2009; Vertovec 2004; Wilding 2006). Drawing on the concept of return preparedness (Cassarino 2004), it follows that transnational ICT use should also empower prospective returnees, enabling them to be better informed about conditions in their homelands and therefore better prepared for a sustainable definitive return. However, as will be discussed here, ICT use among hostel residents may actually serve to impede return, by exacerbating the pressures to remit and amplifying the family tensions noted above.

Advances in transport and communications technologies are held to be central drivers of transnationalism (Faist 2000; Portes et al. 1999). The wider availability of these technologies has transformed transnational activities: no longer the prerogative of business elites, transnational practices are part of everyday life for a growing share of migrants (Portes et al. 1999). Much attention has been focused on web technologies in the globalisation literature and migrants are often perceived at the "cutting edge" when it comes to adoption of such technologies (Panagakos and Horst 2006: 111). While some migrants do indeed have the potential at their fingertips to play this pioneering role, such a generalization should be qualified by acknowledging that not all migrants possess the financial and human capital needed to exploit these opportunities to the full. A point on which there appears to be scholarly agreement is that older people are not easily able to manipulate ICT (Hamel 2009; Panagakos and Horst 2006; Tall 2004). Internet-based technologies continue to inspire the lion's share of scholarly enquiry in the field of migrants' ICT use (for example, Oiarzabal and Reips 2012). Less attention has been given to how developments associated with the 'seemingly pedestrian' technology of long-distance telephony link with international migration (Panagakos and Horst 2006: 111-12). Yet Steven Vertovec insists that "nothing has facilitated processes of global linkage more than the boom in ordinary, cheap international telephone calls. This is especially the case among non-elite social groups such as migrants" (Vertovec 2004: 219). Within this non-elite group, ageing migrants experiencing literacy problems may be especially receptive to advances in this technology. This is the case for the less-skilled migrants who formed Europe's post-WWII 'guestworker' cohort.

Dialling to Dembancané: The All-Conquering Mobile Phone Given the importance of international telephony to migrant communities, rather than speaking of the 'rupture' that new communication technologies are commonly held to represent (Appadurai 1996), Mattelart (2009) argues it is more accurate to describe today's long-distance communication technologies as forming a continuity with the past, encompassing letters, phone calls, tape recordings, and video messages. Certainly, among my respondents, letters and tape-recorded messages were the most popular means of communicating with family up until the 1990s. One or two public call 
boxes were often installed in hostels, but home villages were generally not equipped with telephone facilities. In this regard Dembancané - where I conducted fieldwork for one month - was somewhat exceptional compared with Senegalese villages of a similar size: a post office with fixed-line phone connection existed as early as $1975 .{ }^{4}$ Nonetheless, international calling tariffs remained prohibitively expensive until the 1990s. Preferring the low-cost postal alternative, the Dembancané men living in France were obliged to go long periods without contact:

You could go two months without contact, because when you write and you send a letter to your wife or your mother, well it takes a long time for it to arrive, and then again for the response. Personally I didn't have any problems with writing, but when the letter arrived in the village, it took time for my mother to find someone who writes, because there weren't many 'intellectuals' in the village back then [laughs] (...) To be able to write a letter you had to be something special! (...) Communication was difficult, very difficult, at that time. There weren't any telephones, there weren't any mobiles at that time. (Djimé, Dembancané, Senegal)

It was only in the 1990 s that the price barriers to international telecommunications fell, thanks to deregulation and the improved carrying capacity of new fibre optic lines (Warf 2013). These developments heralded a sudden and quite startling exponential growth in international call volumes. ${ }^{5}$ Vertovec (2004) cites research which shows that the use of low-cost phone cards doubled between 2000 and 2002, and that over half of all calling card traffic was international. Moving to the specifics of the French case, a study by Pasquier (2001) noted the availability of pre-paid phone cards for North and West African migrants in France from the second half of the 1990s. These considerably reduced the costs of calls, which up until then had been a major worry for migrants and their families (Mattelart 2009). These evolutions at the global level are also mirrored at the local level in the village of Dembancané. There we see a boom in the use of fixed-line phones to communicate with loved ones living abroad and elsewhere in Senegal, and the opening of commercially-operated telephone cabins (téléboutiques) to serve this demand.

The Dembancané téléboutique opened in the late-1990s. Yet a mere decade after opening, it lies empty and obsolete, eclipsed by the all-conquering mobile phone. This change has been extremely rapid, occurring in the last 10 years. In 2004-2005, less than a third of the surveyed hostel residents in the Paris region affirmed having personal access to either a landline or a mobile (Bitatsi Trachet and El Moubaraki 2006). Yet, by 2008-2009, when this research was conducted, almost all my respondents owned a mobile handset, and some owned quite advanced models. However, such technology is best able to exploit its potential for cheap international communication purposes only if one's interlocutors back home also possess such devices. The comparative advantage of mobile networks over fixed line infrastructure, in terms of cost and ease of installation, has heralded a recent boom in mobile phone

\footnotetext{
${ }^{4}$ For example, the landline telephone was "just becoming known" in the village of M'Benguène when Mansour Tall undertook research there in the early 2000s (Tall 2004: 31).

${ }^{5}$ In 1982, international call minutes stood at 12.7 billion. By 1992 this figure had risen to 42.7 billion, and by 2001 to 154 billion minutes (Vertovec 2004).
} 
use in many developing countries (Warf 2013). Morocco and Senegal are no exceptions to this trend. Wherever I went in both countries, mobile phones were much in evidence and I was often invited to swap numbers with friends and relatives of my hosts. Furthermore, it was easy to find kiosks where top-up call-time could be purchased, even in small villages and at road-side stalls. These developments were summed up well by Souleymane:

Until recently, no one had mobile phones, there were just fixed lines in France in the hostel, and maybe one or two fixed lines in the village in West Africa. But now everyone's got a mobile, both in the hostel but more importantly also in the country of origin. Every wife has a phone, so the men are constantly in communication with their families back home. (Souleymane, 50s, Mauritania)

For hostel residents, the consequence of this boom in communications infrastructure is that use of international telecommunications technology, be it fixed-line or mobile, has become a daily part of life in a very short space of time. Many of my respondents, when asked, affirmed to engaging in daily or near-daily telephone calls with family. Furthermore, my interviews were often punctuated by incoming phone calls from home. The everyday banality which the mobile phone represents for hostel residents has also been documented by other authors in different migration contexts (Tazanu 2012; Thompson 2009).

\section{ICT and Return Preparedness: Mobilizing Influence and Managing}

Expectations Although not without nuance, much of the literature on mobile phone use among transnational migrants has tended to celebrate the mobile phone, positively evaluating the benefits of better quality, cheaper and more regular communication. This literature tends to attribute an empowering role to information and communication technologies when taken up by marginal or precarious populations. Heather Horst describes how "[f]or many Jamaicans without access to a regular or reliable phone service prior to 2001, the mobile phone is viewed as an unadulterated blessing, transforming the role of transnational communication from an intermittent event to a part of daily life" (Horst 2006: 143). Similarly, as Tall enthuses in a study of mobile and fixed line phone use among Senegalese émigrés and their left behind families, "ICTs are a factor in achieving progress, a source of power that encourages people to access that power, a powerful element of social innovation" (Tall 2004: 47). Other positive appraisals of the technology abound. In Wilding's study, some of her respondents depicted this new technology as a "miracle" (Wilding 2006: 131). Similarly, although Horst rightly notes certain disadvantages of transnational mobile phone use such as the cost of handsets and the phone's potential as a tool of unwelcome surveillance, she concludes that "it was difficult to ignore the blessings of the mobile phone" (Horst 2006: 154). Other commentators speak of mobile phones in the developing world as a 'pro-poor' technology (Mallalieu 2006). Much has been made of ICTs' potential to contribute to human development (Hamel 2009): a much-cited study from 2005 calculated that an increase of ten mobile phones per 100 people in developing countries in Africa increases GDP growth by $0.6 \%$ (Waverman et al. 2005). Finally, Steven Vertovec describes how the unprecedented 
volumes of "cheap telephone calls serve as a kind of social glue" for migrants and their home communities (Vertovec 2004: 220), a finding echoed by Benítez (2012).

Beyond ICT's well-documented empowering effects on immigrants and their stay-at-home families, an emerging literature has charted its influence in facilitating migration flows. Appadurai (1996) argued that the globally-diffused images and sound bites of electronic media that generate 'diasporic public spheres' are instrumental in precipitating all sorts of migration flows. Perkins and Neumayer (2013) suggest that chain migration may be stimulated by ICTs through exchanges between potential migrants and those who have already emigrated. Furthermore, mobile phones and other communication technologies are central in facilitating not only the flights of imagination that inspire would-be migrants, but also in facilitating the logistics of travel that some subsequently undertake. Qualitative fieldwork with subSaharan 'transit' migrants in North Africa has demonstrated how critical a mobile phone can be during the dangerous and 'fragmented' journey to Europe (Collyer 2007; Schaub 2012).

Innovations in return migration theory also point to an important role for mobile phones and other forms of ICT in empowering return migration. The concept of 'return preparedness', proposed by Jean-Pierre Cassarino (2004), builds on earlier 'structuralist' accounts of return migration which contended that for return to be sustainable, migrants must readapt to social norms and economic and political structures in the place to which they return (see Chap. 2 for a discussion). Authors working from this perspective tended to be pessimistic about the sustainability of return as they assumed that most prospective returnees become too detached from such norms and institutions in places of origin and are therefore 'ill prepared for their return' (Gmelch 1980: 143). Cassarino builds on this earlier focus on preparing for return by drawing on insights from the literature on transnationalism and social networks as drivers of migration. He contends that some migrants are better prepared for return thanks to the efforts and time they invest in mobilizing financial, human and social capital in both sending and receiving countries (Cassarino 2004). Clearly, the transnational exchange of information is crucial to boosting return preparedness. Hence, different types of ICT (internet, email, telephone) may be of great utility in preparing for return.

One aspect of return preparedness in the existing literature is how mobile phones facilitate new (or renewed) influence over close relatives (and extended kin members) who were previously out of reach. This potentially can cement a prospective returnee's place in the family and home community, for example through household budgeting and remittance sending. In her study of mobile phone use in Jamaican transnational fields, Horst (2006) notes that in the past sending money by post was unreliable and very time-consuming. Mail was problematic because it could be intercepted or lost or "simply did not reach the recipient in time for them to make effective use of the sum sent" (Hamel 2009: 20). Since the widespread adoption of mobile telephony in many developing countries and migrant sending regions, studies have found that phones can be used for the 'micro-coordination' of remittance transfers and to specify how the money sent is to be used (Horst 2006: 153; Perkins and Neumayer 2013; Tazanu 2012). As with household budgets, fixed and mobile 
phone technologies can be harnessed to coordinate and manage household activities (Hamel 2009; Thompson 2009; Wilding 2006), potentially giving migrants more influence over family members previously out of reach. Critically for this discussion, researchers have also found that such technology can be used by emigrants to better manage the expectations of their loved ones back home. Horst argues that "the increased communication enabled through the presence of house phones and especially the ownership of mobile phones has led [left behind] Jamaicans to more realistic expectations of the migration experience" (Horst 2006: 155).

The 'Pressure of Communicability' On first inspection, these positive evaluations of mobile phone use and other information technologies as facilitating transnational communication and managing expectations are hardly surprising: what could be problematic about cheaper, more regular and better quality communications between migrants and their loved ones in countries of origin? However, a different picture emerged during the fieldwork for this book. While intuitively one would expect cheaper and better quality communications between hostel residents and their families to empower return by boosting return preparedness, this was far from always the case.

For some respondents, these new technologies were positively viewed. As Hamid (70, Taroudant, Morocco) pointed out, before the coming of the mobile phone, the only way to maintain contact was by letter. As described above, communication by letter was a painfully long and intermittent process. By contrast, when we met in 2009, Hamid spoke of daily phone calls to his wife and children. He also talked about sending text and photo messages, and about his family calling him over the internet using VoIP (Voice over Internet Protocol) applications such as Skype. These technological developments are changes for the better in his opinion. The same applied to money transfers: before it would take 15 or 20 days for the postal mandat to arrive in his Moroccan hometown. Nowadays, money wired by Western Union would arrive in an instant.

The speed of money transfer services such as Western Union was seen as a notable advance, and the mobile phone was essential in requesting these transfers and coordinating their timing.

When they need food, or anything else, they call me, then I send immediately what is required. [So you are often in contact?] Oh yes, always in contact, to see if they have everything they need at home, so when they lack something, they get the money straight away. (Hadyatou, Dembancané, Senegal)

The money arrives immediately, but they call to check you've sent it too! (Issa, 70, Tambacounda, Senegal)

While the instantaneous nature of money transfers was applauded, Issa's quote here does hint at a less welcome feature of mobile phone use for hostel residents, namely that hostel residents are now more 'available and reachable' to left behind kin (Tazanu 2012). The potential of mobile phones to generate more measured expectations of the migrant from those remaining behind was not a feature of hostel residents' narratives. Quite the opposite, as the epigraph at the start of this chapter showed. Their exchanges with family members back home were not always affec- 
tionate or attentive, but instead revolved around the apparently ever-increasing financial needs of the household. In interviews, hostel residents complained of the 'pressure' they felt to attend to these needs. With the advent of the mobile phone it had become less and less possible to ignore these expectations emanating from home. Mobile phones were identified by my respondents as a key factor in exacerbating this sense of responsibility. Souleymane (50s, Mauritania), a member of his hostel's Residents' Committee, aptly described this as "the pressure of communicability" (la pression de la communicabilité):

Every wife has a phone, so the men are constantly in communication with their families back home. And this creates a certain pressure; you are much more aware of everything going on in the village, and your responsibilities weigh more heavily. (Souleymane, 50s, Mauritania)

Intriguingly, few scholars of migration and ICTs have written about these pressures. This inattention to the remittance 'burden' generated by ICTs may be related in part to the fact that the remittance literature tends to focus on recipients in the country of origin, not the senders abroad, as Anna Lindley (2009) has critiqued. Although not addressing the topic directly, Vertovec hints at such pressures when he comments that "[f]or migrants and their kin in distant parts of the world, telephone calls can only provide a kind of punctuated sociality that can heighten emotional strain as well as alleviate it" (Vertovec 2004: 223). Primus Tazanu's monograph about the use of ICT in Cameroonian transnational social fields goes further by explicitly highlighting the potential of new technologies to foment grudges between Cameroonians living in Europe and their left behind relatives and friends, particularly when it comes to coordinating remittances (Tazanu 2012). This same phenomenon is touched on by Raelene Wilding, who notes that "in some cases the availability of contact created its own anxieties - particularly when kin used ICTs to demand remittances from the refugees" (Wilding 2006: 135). Likewise, Stephanie Riak Akuei (2005) describes similar dynamics among Dinka refugees from southern Sudan living in San Diego: some of her respondents went so far as to change their phone numbers to avoid such demands, without informing family members, something also reported by Lindley (2009) in her study of Somalis in London.

While none of my own respondents admitted changing their phone number for this reason, several made a link between the increasing burden of their responsibilities and the advent of improved telecommunications. Amadou (64, Tambacounda, Senegal) talked about being in regular contact with home via his mobile phone, concluding that "all in all there are many responsibilities: you have to give to almost everyone." For others, the dissonance created by being simultaneously far away (in body) but within earshot was an unwelcome break with the 'easy life' of the past, when intensive transnational communication was rare:

Before, life was easy, there was no difficulty. Because we weren't sending money like nowadays, like all the time. We used to send money at the end of the month. Now, all the time, they ask you for money, one person's ill, the other one needs this, the other that, it's not like before (...) These days, there's Western Union, there's Moneygram, there's the fax, there's all that. (...) Nowadays, if they have a problem back home, it comes straight back to you. (Issa, 70, Tambacounda, Senegal) 
Given that the literature on ICTs tends to stress both the developmental and empowering virtues of this technology, and the lower take-up of such technology among older people, one would be forgiven for thinking that older hostel residents who use this technology would figure among the most empowered of all senior citizens. In fact, the findings show that ICTs may serve to exacerbate or amplify the men's burdens, calling into question the empowerment thesis. The new communications technology, while a blessing in some ways, makes it easier for left behind relatives to 'exploit' family connections for money and other forms of remittance. Saleem, in particular, returned again and again during our discussions to the motif of exploitation, both in France and back home.

I don't feel at ease, because I feel that - I feel I am alone, and I am still exploited - exploited by those who are here [in France] and those who are there [back home] (...) It's true that it's my family, but I'm exploited all the same, because I don't have a choice. Well, if they have bills to pay, it's me who pays, because they don't have anyone else. (Saleem, 60, Tiznit, Morocco)

\subsection{Conclusion}

This chapter has described how remittances have long been a way of life for the hostel residents and their families, sustaining the existence of both recipients and senders, be that materially or socially. The French government's migrant worker hostel policy itself was designed to facilitate such transfers: by keeping rents low, the men were able to send as much money as possible back home, thereby discouraging family reunification (Viet 1999). The men who remain in the hostels past retirement have internalised this logic, to the point that remittance sending has become an institutionalised practice. Subsistence needs are the first item of expenditure, but beyond this minimum expectation, remittances are also deployed to boost the social standing of families and to diversify household income streams. Such strategies include investments in property for rental purposes; investments in agricultural technology leading to greater productivity; and investments in children's education. The latter was identified as particularly important following the retirement of hostel residents in France, since children who have good jobs are able to fulfil the expectation of support for their parents in old age.

In relating these themes back to my main interest in late-in-life return, the importance of remittances would appear to lend strong support to the explanatory power of the new economics of labour migration (NELM), as presented in Chap. 2. However in some cases the NELM logic appears to be distorted. Although the theory predicts that the passage to retirement of geographically single migrant workers heralds the end of the migration project and subsequent return to rejoin family in the place of origin, in some cases children and grandchildren remain dependent on the reduced income of the pensioner. This prompts some older men to remain in France after retirement, in order to satisfy eligibility rules for welfare entitlements which boost their pension income. As a result they become trapped in France. 
In turn, remittance dependency has contributed to conflicts with spouses, children and siblings, as was described in Sect. 5.3. Role loss was identified as a pertinent process here. Role loss is commonly identified as an outcome for older people in (post-) industrialised countries, especially for men following the passage to retirement (Gordon 1972). On the one hand, the men have not lost their role of principal breadwinner, despite the transition to retirement and exit from the labour market: on the other hand, years of separation have led to loss of patriarchal authority within the family. It appears that the gendered and generation-specific role of 'migrant breadwinner' is a dominant social and economic role which some older hostel residents are expected to maintain, but this norm becomes a constraint to return at retirement age (see Hunter 2015b for further discussion). The insights about family conflict in this chapter thus support the contention that family connections are not only a factor in encouraging return migration at retirement, but may also impede it, when family members have clashing expectations or priorities (Percival 2013). De Haas and Fokkema (2010) argue that the NELM approach tends to 'reify' the household, ascribing to it common goals, equal power relations and unanimous decision-making, and ignoring the potential for conflict between more and less powerful members, frequently along the dividing lines of gender and generation. These divisions may come to the fore especially over the question of return. As de Haas and Fokkema argue, "family reunification can empower women and children, who generally oppose return, and it seems to have pushed many men into strategies of pendulum migration" (de Haas and Fokkema 2010: 558). The research presented in this chapter suggests that not reunifying may also sometimes empower left behind wives and children, ${ }^{6}$ leading to family tensions during the return visits of the hostel residents and precipitating their early departure back to the 'refuge' of the hostel in France.

Remittance dependency and family conflicts are amplified by advances in telecommunications technology. Transnational communications between family members used to be slow and intermittent. While the enforced separation and prolonged silence were painful to bear, one silver lining for hostel residents was that there were fewer responsibilities weighing on them. With the advent of new communication technologies this situation has been reversed: low-cost fixed and mobile telephony has resulted in greater "pressure of communicability". Theories of transnationalism consider such technology as an explanatory variable: easier and more regular communication should facilitate return migration, since prospective returnees will be better prepared for their return, a factor stressed by structuralist accounts. However, the opposite may ensue: in contrast to literature which ascribes to ICT a pro-poor and developmental role which empowers people, these new technologies sometimes make it easier for relatives to 'exploit' family connections for remittances, thereby impeding return.

\footnotetext{
${ }^{6}$ See also Lenoël 2017 for a nuanced treatment of this topic.
} 


\section{References}

Aggoun, A. (2006). Né ailleurs, vieillissant ici : La poursuite de l'immigration à la retraite. Annales de La Recherche Urbaine, 100, 129-136.

Appadurai, A. (1996). Modernity at large: Cultural dimensions of globalization. Minneapolis: University of Minnesota Press.

Barou, J. (2001). Etre père à distance : le devenir des enfants demeurés au pays d'origine. Paris: Sonacotra/UNICEF.

Benítez, J. L. (2012). Salvadoran transnational families: ICT and communication practices in the network society. Journal of Ethnic and Migration Studies, 38(9), 1439-1449.

Bensaïd, M., \& Ibourk, A. (2008). Impact social des transferts de fonds des Marocains résidant à l'étranger: une revue de littérature, Division of Policy and Practice Working Paper. New York: UNICEF.

Berrada, A. (2009). Les remises d'épargne des MRE et leurs caractéristiques. In B. Hamdouch \& A. El Ftouh (Eds.), Remises d'épargne des migrants: expériences et perspectives (pp. 23-38). Rabat: Fondation Hassan II.

Berrianne, M., \& Hopfinger, H. (1992). Migration internationale de travail et croissance urbaine dans la province de Nador (Maroc). Revue Européenne des Migrations Internationales, 8(2), 171-190. https://doi.org/10.3406/remi.1992.1328.

Bitatsi Trachet, F., \& Moubaraki, M. E. (2006). Prise en charge du vieillissement de la population en foyers de travailleurs migrants et résidences sociales. Migrations Santé, 127(8), 97-114.

Bourdieu, P. (1965). The sentiment of honour in Kabyle society. In J.G. Peristiany (Ed.), Honour and shame: The values of mediterranean society (P. Sherrard, Trans.) (pp. 191-241). London: Weidenfeld and Nicolson.

Bourqia, R., El Melakh, K., Abdourebbi, M., \& Nafaa, R. (2007). Etude exploratoire sur l'émigration et ses impacts socioculturels sur la société locale. In M. Khachani (Ed.), L'impact de la migration sur la société marocaine (pp. 151-225). Rabat: Goethe-Institut/AMERM/GTZ.

Carling, J. (2014). Scripting remittances: Making sense of money transfers in transnational relationships. International Migration Review, 48, S218-S262.

Cassarino, J.-P. (2004). Theorising return migration: the conceptual approach to return migrants revisited. International Journal of Multicultural Societies, 6(2), 253-279.

Cerase, F. P. (1974). Expectations and reality: A case study of return migration from the United States to Southern Italy. International Migration Review, 8(2), 245-262.

Collyer, M. (2007). In-between places: Trans-Saharan transit migrants in Morocco and the Fragmented journey to Europe. Antipode, 39(4), 668-690. http://doi. org/10.1111/j.1467-8330.2007.00546.x.

de Coulon, A., \& Wolff, F.-C. (2006). The location of immigrants at retirement: Stay/Return or "Va-Et-Vient"? (No. 2224). Bonn: Institute for the Study of Labor (IZA).

de Haas, H. (2006). Migration, remittances and regional development in Southern Morocco. Geoforum, 37(4), 565-580. https://doi.org/10.1016/j.geoforum.2005.11.007.

de Haas, H., \& Fokkema, T. (2010). Intra-household conflicts in migration decisionmaking: Return and pendulum migration in Morocco. Population and Development Review, 36(3), 541-561. https://doi.org/10.1111/j.1728-4457.2010.00345.x.

Faist, T. (2000). The volume and dynamics of international migration and transnational social spaces. Oxford: Clarendon Press.

Gallou, R. (2005). Les immigrés isolés : la spécificité des résidants en foyer. Retraite et Société, $44,106-147$.

Ginesy-Galano, M. (1984). Les Immigrés hors la cité : le système d'encadrement dans les foyers : 1973-1982. Paris: Éditions l'Harmattan/CIEM.

Gmelch, G. (1980). Return migration. Annual Review of Anthropology, 9, 135-159.

Gordon, C. (1972). Role and value development across the life cycle. In J. A. Jackson (Ed.), Role (pp. 65-105). Cambridge: Cambridge University Press. 
Hamel, J.-Y. (2009). Information and Communication Technologies and Migration (No. 39). New York: United Nations Development Programme.

Hmed, C. (2006). Habitat et parcours de vie: approche sociologique du vieillissement des immigrés en foyers pour travailleurs migrants. Migrations Santé, 127(8), 115-141.

Horst, H. A. (2006). The blessings and burdens of communication: Cell phones in Jamaican transnational social fields. Global Networks, 6(2), 143-159.

Hunter, A. (2015a). Empowering or impeding return migration? ICT, mobile phones, and older migrants' communications with home. Global Networks, 15(4), 485-502.

Hunter, A. (2015b). "Family values": la dépendance familiale sur les transferts d'argent et le dilemme de retour au pays d'origine en âge avancé. Hommes et Migrations, 1309, 117-125.

Jónsson, G. (2011). Non-migrant, sedentary, immobile, or 'left behind'? IMI Working Paper Series No. 39. Oxford: International Migration Institute.

King, R. (Ed.) (1986). Return migration and regional economic development: An overview. In: Return migration and regional economic problems (pp. 1-37). London: Croom Helm.

Klinthäll, M. (2006). Retirement return migration from Sweden. International Migration, 44(2), $153-180$.

Lacroix, T. (2005). Les réseaux marocains du développement: géographie du transnational et politique du territorial. Paris: Presses de Sciences Po.

Lenoël, A. (2017). The "three ages" of left-behind Moroccan wives: Status, decision-making power and access to resources. Population, Space and Place. http://doi.org/10.1002/psp.2077.

Les Echos. (1971, July 23). Economes et peu payés, les travailleurs immigrés sont le plus souvent mal logés.

Lindley, A. (2009). The early-morning phonecall: Remittances from a refugee diaspora perspective. Journal of Ethnic and Migration Studies, 35(8), 1315-1334.

Madianou, M. (2012). Migration and the accentuated ambivalence of motherhood: The role of ICTs in Filipino transnational families. Global Networks, 12(3), 277-295.

Mallalieu, K. (2006). Pro poor mobile capabilities: Service offering in Latin America and the Caribbean. Lima: DIRSI.

Manchuelle, F. (1997). Willing migrants: Soninke Labor Diasporas, 1848-1960. Athens: Ohio University Press.

Mattelart, T. (2009). Les diasporas à l'heure des technologies de l'information et de la communication: petit état des savoirs. Tic \&société, 3(1-2), 11-57.

Mernissi, F. (2003). Beyond the veil: Male-female dynamics in modern muslim society (Revised ed.). London: Saqi Books.

Mondain, N., \& Diagne, A. (2013). Discerning the reality of 'Those left behind' in contemporary migration processes in Sub-Saharan Africa: Some theoretical reflections in the light of data from Senegal. Journal of Intercultural Studies, 34(5), 503-516.

Obeng-Odoom, F. (2010). Urban real estate in Ghana: A study of housing-related remittances from Australia. Housing Studies, 25(3), 357-373.

Oiarzabal, P. J., \& Reips, U.-D. (2012). Migration and diaspora in the age of information and communication technologies. Journal of Ethnic and Migration Studies, 38(9), 1333-1338.

Panagakos, A. N., \& Horst, H. A. (2006). Return to Cyberia: Technology and the social worlds of transnational migrants. Global Networks, 6(2), 109-124.

Parreñas, R. S. (2005). Children of global migration: Transnational families and gendered Woes. Stanford: Stanford University Press.

Pasquier, D. (2001). «La famille, c'est un manque »: Enquête sur les nouveaux usages de la téléphonie dans les familles immigrées : médias et migrations. Réseaux, 107, 181-208.

Percival, J. (2013). Concluding reflections. In J. Percival (Ed.), Return migration in later life: International perspectives (pp. 241-247). Bristol: Policy Press.

Perkins, R., \& Neumayer, E. (2013). The ties that bind: The role of migrants in the uneven geography of international telephone traffic. Global Networks, 13(1), 79-100.

Portes, A., Guarnizo, L. E., \& Landolt, P. (1999). The study of transnationalism: Pitfalls and promise of an emergent research field. Ethnic and Racial Studies, 22(2), 217-237. 
Quiminal, C. (2002). Retours contraints, retours construits des émigrés maliens. Hommes et Migrations, 1236, 35-43.

Riak Akuei, S. (2005). Remittances as unforeseen burdens: The livelihoods and social obligations of Sudanese refugees. Geneva: GCIM.

Schaub, M. L. (2012). Lines across the desert: Mobile phone use and mobility in the context of trans-Saharan migration. Information Technology for Development, 18(2), 126-144.

Sharabi, H. (1988). Neopatriarchy. A theory of distorted change in Arab Society. New York/ Oxford: Oxford University Press.

Stark, O. (1991). The migration of labor. Oxford: Basil Blackwell.

Tall, S. M. (2004). Senegalese émigrés: New information \& communication technologies. Review of African Political Economy, 31(99), 31-48.

Tazanu, P. M. (2012). Being available and reachable: New media and cameroonian transnational sociality. Bamenda: Langaa Research \& Publishing.

Thompson, E. H. (2001). Older men as invisible men in contemporary society. In B. A. Arrighi (Ed.), Understanding inequality: The intersection of racelethnicity, class, and gender (pp. 261268). Lanham/Oxford: Rowman \& Littlefield.

Thompson, E. C. (2009). Mobile phones, communities and social networks among foreign workers in Singapore. Global Networks, 9(3), 359-380.

Vertovec, S. (2004). Cheap calls: The social glue of migrant transnationalism. Global Networks, $4(2), 219-224$.

Viet, V. (1999). La politique du logement des immigrés (1945-1990). Vingtième Siècle. Revue D'histoire, 64(1), 91-103.

Warf, B. (2013). Geographies of global telephony in the age of the internet. Geoforum, 45, 219-229.

Waverman, L., Meschi, M., \& Fuss, M. (2005). The impact of telecoms on economic growth in developing countries. InAfrica: The impact of mobile phones (pp. 10-23). Newbury: Vodafone Group.

Wilding, R. (2006). "Virtual" intimacies? Families communicating across transnational contexts. Global Networks, 6(2), 125-142.

Wyman, M. (1993). Round-trip to America: the immigrants return to Europe, 1880-1930. Ithaca: Cornell University Press.

Open Access This chapter is licensed under the terms of the Creative Commons AttributionNonCommercial 4.0 International License (http://creativecommons.org/licenses/by-nc/4.0/), which permits any noncommercial use, sharing, adaptation, distribution and reproduction in any medium or format, as long as you give appropriate credit to the original author(s) and the source, provide a link to the Creative Commons license and indicate if changes were made.

The images or other third party material in this chapter are included in the chapter's Creative Commons license, unless indicated otherwise in a credit line to the material. If material is not included in the chapter's Creative Commons license and your intended use is not permitted by statutory regulation or exceeds the permitted use, you will need to obtain permission directly from the copyright holder.

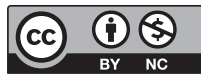

